\title{
Adhesion and Signalling Molecules Controlling the Extravasation of Leukocytes across the Endothelium
}

\author{
Britta Engelhardt \\ Theodor Kocher Institute, University of Berne, Switzerland
}

\author{
Key Words \\ Leukocyte trafficking - Blood vessels . \\ Adhesion molecules
}

\section{Summary}

To ensure proper immunosurveillance, lymphocytes continuously recirculate throughout our body searching for their specific antigens. For their transportation to the distant destinations they use the blood vessels, which they leave once they have reached their target tissue. Lymphocytes exit the different organs via the lymphatic vascular system, which due to its connection to the venous blood stream allows the immune cells to re-enter the blood stream. Lymphocyte recirculation is not random, rather a sophisticated navigation system allows immune cells to 'read' organ-specific traffic signals posted at the blood vessel wall within each organ. These traffic signals ensure that the appropriate immune cell reaches its proper location at the right time. Here, I will describe the steps involved in immune cell trafficking in our body and briefly introduce the molecular nature of the immune cell navigation system and the vascular traffic signals required for this process.

\section{Immune Cell Subpopulations Travel on Cell-Specific Routes}

Immune cells of the innate and the adaptive immune system are built in the bone marrow. Whereas most immune cells fully mature at this site, immature $\mathrm{T}$ lymphocytes leave the bone marrow via the blood stream to reach the thymus, where

\author{
Schlüsselwörter \\ Leukozytenrezirkulation · Blutgefässe · \\ Adhäsionsmoleküle
}

\section{Zusammenfassung}

Auf der Suche nach ihrem spezifischen Antigen wandern Immunzellen ständig durch unseren Körper und gewährleisten so die Immunüberwachung. Als Transportwege verwenden sie die Blutgefäße, die sie rasch zu ihren weit entfernten Zielorganen bringen. Vom Zielorgan gelangen Immunzellen über lymphatische Gefäße wieder zurück in den venösen Blutkreislauf. Die Rezirkulation der Immunzellen ist dabei nicht dem Zufall überlassen, vielmehr verfügen diese Zellen über ein ausgeklügeltes «Navigationssystem" mit Hilfe dessen sie organspezifische "Verkehrsschilder" an der Blutgefäßwand erkennen können. Diese Verkehrssignale gewährleisten, dass die richtige Immunzelle zum richtigen Zeitpunkt jeweils an den richtigen Ort gelangt. In diesem Artikel beschreibe ich die einzelnen Schritte, welche bei der Immunzellrezirkulation in unserem Körper beteiligt sind und stelle in diesem Zusammenhang kurz die molekulare Natur des Immunzell-Navigationssystems und der vaskulären Verkehrssignale, welche für diesen Prozess benötigen werden, vor.

they finish their maturation into the different T-cell subsets. From these sites antigen-inexperienced immune cells from the adaptive immune system, i.e. naive B and T lymphocytes, travel via the blood stream to the secondary lymphoid organs such as the spleen and the lymph nodes. If they do not encounter their specific antigen in these organs they eventually re-enter the circulation. In contrast, antigen-experienced $\mathrm{T}$ and $\mathrm{B}$ lym-

\begin{tabular}{ll}
\hline KARGER & $\oplus$ 2008 S. Karger GmbH, Freiburg \\
Fax +49 7614520714 & Accessible online at: \\
$\begin{array}{l}\text { E-mail Information@Karger.de } \\
\text { www.karger.com }\end{array}$ & www.karger.com/tmh
\end{tabular}

\section{KARGER}

www.karger.com
Prof. Dr. Britta Engelhardt

Theodor Kocher Institute, University of Berne

Freiestrasse 1, 3012 Bern, Switzerland

Fax +41316313799

E-mail bengel@tki.unibe.ch 
phocytes do not travel to the secondary lymphoid organs. In contrast, depending on their previous site of antigen-specific activation, they preferentially travel to those organs that drain lymph into their previous activation site. Finally, once there is an acute injury in a given organ in our body, immune cells are preferentially re-directed to this affected site.

\section{Orientation of Immune Cells within the Blood Stream}

How can immune cells orient themselves inside of blood vessels? If we imagine a white blood cell traveling inside a blood vessel, it is easy to compare this situation with somebody driving an automobile inside a tunnel. Even if the tunnel is brightly light, it would be impossible for the driver to judge what is beyond the tunnel's concrete walls, except there are traffic signs posted at the tunnel walls showing the car driver the way. In fact, in quite a comparable manner, organ-specific traffic signals are posted on the walls of blood vessels, which allow immune cells to orient themselves. In further analogy to automobile traffic, endothelial cells lining the walls of postcapillary venules post advance direction signs before the final exit sign allowing the immune cell, which arrives with high velocity in the blood stream, to adjust its speed, to slow down, and finally to stop on the vessel wall before extravasating into the target organ (fig. 1a). Depending on their function immune cells are equipped with a navigation system that targets them to the correct target organ. Unlike the automobile traffic, however, traffic signals and immune cell navigation systems consist of membrane-bound and soluble glycoproteins and lipids which serve as adhesion and signalling molecules directing immune cell traffic.

\section{Molecular Nature of the Traffic Signals Regulating the Multi-Step Leukocyte Recruitment}

The multistep nature of leukocyte extravasation from the blood stream into the tissue was first described by Eugene C. Butcher [1] and Timothy Springer [2].

The initial transient contact of the circulating leukocyte with the vascular endothelium reduces its velocity in the blood stream from 1,000 to $4,000 \mu \mathrm{m} / \mathrm{s}$ to a rolling velocity on the endothelium of 5 to $40 \mu \mathrm{m} / \mathrm{s}$ [3]. Initial capture and rolling are generally mediated by adhesion molecules of the selectin family and their respective carbohydrate ligands [4].

The endothelial selectins, P-selectin and E-selectin are only expressed on the endothelial cell surface during inflammation. P-selectin is stored in Weibel-Palade bodies of endothelial cells and is rapidly translocated to the cell surface within minutes upon their activation by inflammatory stimuli such as bacteria or cytokines. Slightly later de novo expressed E-selectin will be induced on the endothelial cell surface during inflammation. Thus, during acute injury or inflammation

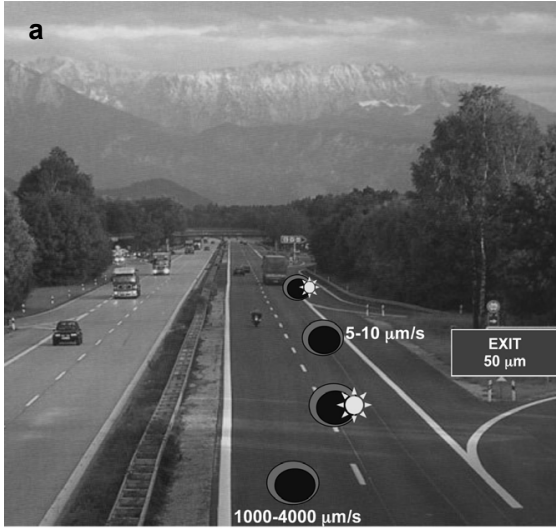

Fig. 1. The multistep model of leukocyte endothelial interaction. a In analogy to automobiles aiming to leave a freeway, immune cells can be imagined to leave the blood stream in a sequence of steps involving their 'reading' of an advance direction sign, reducing their velocity, 'changing the lane' and margining to the vessel wall and finally 'reading' the exit sign and leaving the freeway/blood stream. b Molecular steps involved in the multistep leukocyte extravasation from the blood stream into the tissue details are explained within the text.

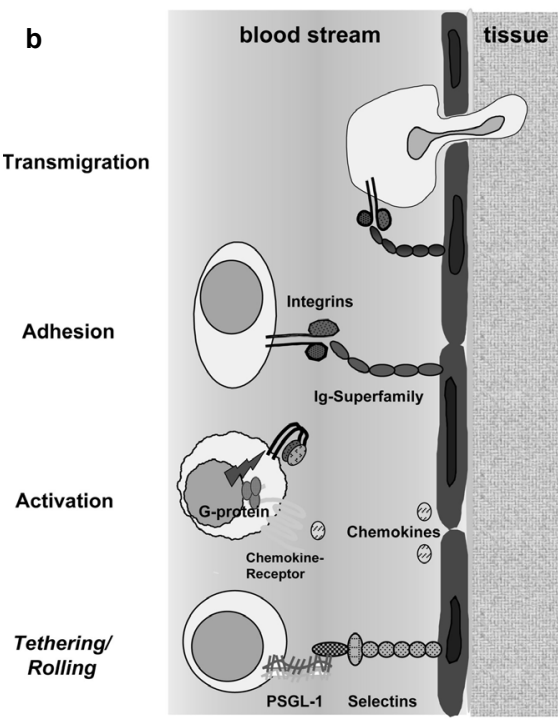

P-and E-selectin serve as traffic signals, which rapidly 'deviate' immune cells into the affected organ.

Via their N-terminal lectin domain selectins recognize fucosylated and sialylated glycoprotein ligands. P-selectin glykoprotein ligand 1 (PSGL-1) has been most extensively characterized and is expressed on all lymphocytes, monocytes, eosinophils and neutrophils [5]. It is the major ligand for P-selectin but can also bind to E-selectin (fig. 1b).

In contrast to the endothelial selectins, L-selectin is constitutively expressed on all circulating leukocytes. L-selectin glykoprotein ligands have been identified in high endothelial venules (HEVs) of secondary lymphoid organs and are collectively know as the peripheral node addressins (PNAd) and recognized by the monoclonal antibody MECA-79 [6]. L-selectin mediates the rolling of naive lymphocytes on PNAd in HEVs of peripheral lymph nodes.

In a next step the rolling leukocyte can recognize chemotactic factors from the family of chemokines presented in an organspecific manner on the endothelial surface. Chemokines are a family of about 50 low molecular weight chemotactic cytokines $(8-14 \mathrm{kDa})$ that are divided into four groups (CC, $\mathrm{CXC}, \mathrm{CX}_{3} \mathrm{C}$ and $\mathrm{C}$ ) based on the orientation of conserved cys- 
teins in their amino terminus [7]. Chemokines bind to their respective serpentine receptors, which are grouped accordingly into four receptor families (CCR, CXCR, $\mathrm{CX}_{3} \mathrm{CR}$ and $\mathrm{CR}$ ) on the leukocyte surface. These receptors deliver a G-protein-mediated pertussis toxin-sensitive signal into the cell, resulting in the functional activation of a second part of the leukocyte's navigation system which is the adhesion molecules of the integrin family. Integrins are heterodimers consisting of an $\alpha$ - and a $\beta$-chain residing in an inactive, i.e. bend, conformation on the cell surface. 'Functional activation' of integrins on the leukocyte surface is achieved by a conformational change characterized by the unfolding of the integrin [8].

Only 'unfolded/activated' integrins are able to 'read' the next set of traffic signals posted on the vascular surface. This is achieved by the integrin-mediated firm adhesion of the leukocyte to the vascular endothelium by binding to their endothelial ligands from the immunoglobulin (Ig) superfamily of adhesion receptors. Most important in this interaction are the leukocyte-specific integrins of the $\beta 2$-integrin family. They all share the same $\beta$-chain but consist of different $\alpha$-chains. The $\beta 2$-integrins are a family of 4 receptors, namely LFA-1 ( $\alpha \mathrm{L} \beta 2$; CD11a/CD18), Mac-1 ( $\alpha$ M $\beta 2 ;$ CD11b/CD18), p150.95 ( $\alpha \times 32$; $\mathrm{CD} 11 \mathrm{c} / \mathrm{CD} 18)$ and $\alpha \mathrm{D} \beta 2$ (CD11d/CD18). Especially LFA-1 and Mac-1 are involved in leukocyte extravasation by mediating adhesion to intercellular adhesion molecule-1 (ICAM-1) and ICAM-2 on endothelial cells. Whereas ICAM-2 is constitutively present on the endothelial cells, ICAM-1 is up-regulated during inflammation. Monocytes and lymphocytes can additionally use other integrins such as the $\alpha 4$-integrins. There are two $\alpha 4$-integrins, VLA-4 ( $\alpha 1 \beta 1$, CD $49 \mathrm{~d} / \mathrm{CD} 29)$ and $\alpha 4 \beta 7$ integrin. $\alpha 4 \beta 7$-integrin is the lymphocyte receptor for mucosal addressin cell adhesion molecule-1 (MAdCAM-1). MAdCAM-1 is expressed on postcapillary venules in the lamina propria of the gut and on HEVs of the intestine-associated lymphoid tissues, especially the Peyer's patches and the mesenteric lymph nodes, thus directing trafficking of gut-homing lymphocytes expressing its lymphocyte receptor $\alpha 4 \beta 7$-integrin. Vascular cell adhesion molecule-1 (VCAM-1) is up-regulated on inflamed endothelium directing monocytes and lymphocytes to these sites. Firm adhesion of the leukocyte to the endothelial surface is a prerequisite for diapedesis, which is the step of leukocyte extravasation that is the least well understood. Although it has been demonstrated that transmembrane adhesion molecules found to be concentrated in the lateral borders of the endothelial cells are involved in this process, leukocytes may either extravasate through the endothelial cell contacts or though the endothelial cell itself [9].

\section{Conclusion}

Similar to the sequential steps involved in the exit of a fast driving automobile from the freeway towards its final destination, successful recruitment of circulating immune cells into the tissue depends on the productive interaction of leukocytes with the endothelial cells lining the vessel wall in a series of sequential steps first slowing down the immune cell and then allowing for its safe exit into the tissue. In analogy to automobile traffic immune cell-specific navigation systems and tissuespecific signalization at the vascular wall ensure that immune cell subsets always arrive at the right time at the correct tissue destination.

\section{References}

1 Butcher EC: Leukocyte-endothelial cell recognition: three (or more) steps to specificity and diversity. Cell 1991;67:1033-1036.

$\checkmark 2$ Springer TA: Traffic signals for lymphocyte recirculation and leukocyte emigration: The multistep paradigm. Cell 1994;76:301-314.

3 Butcher EC, Williams M, Youngman K, Rott L, Briskin M: Lymphocyte trafficking and regional immunity. Adv Immunol 1999;72:209-253.
4 Ley K, Kansas GS: Selectins in T-cell recruitment to non-lymphoid tissues and sites of inflammation. Nat Rev 2004;4:325-335.

$\checkmark 5$ Ebnet K, Vestweber D: Molecular mechanisms that control leukocyte extravasation: the selectins and the chemokines. Histochem Cell Biol 1999;112: $1-23$.

6 von Andrian UH, Mempel TR: Homing and cellular traffic in lymph nodes. Nat Rev 2003;3:867-878.
7 Zlotnik A, Yoshie O: Chemokines: a new classification system and their role in immunity. Immunity 2000;12:121-127.

8 Luo BH, Carman CV, Springer TA: Structural basis of integrin regulation and signaling. Annu Rev Immunol 2007;25:619-647.

9 Engelhardt B, Wolburg H: Mini-review: transendothelial migration of leukocytes: Through the front door or around the side of the house? Eur J Immunol 2004;34:2955-2963. 